ISSN: 2302-8556

E-Jurnal Akuntansi Universitas Udayana

Vol.24.3.September (2018):1858-1879

DOI: https://doi.org/10.24843/EJA.2018.v24.i03.p08

\title{
Pengaruh Struktur Aset, Profitabilitas, Operating Leverage, Likuiditas terhadap Struktur Modal Perusahaan Consumer Goods di BEI
}

\author{
I Komang Yusa Dharmadi ${ }^{1}$ \\ I Gusti Ayu Made Asri Dwija Putri²
}

${ }^{1}$ Fakultas Ekonomi dan Bisnis Universitas Udayana (unud), Bali, Indonesia

Email: yusadharmadi94@gmail.com / telp.+6281936018647

${ }^{2}$ Fakultas Ekonomi dan Bisnis Universitas Udayana (unud), Bali, Indonesia

\begin{abstract}
ABSTRAK
Struktur modal adalah perimbangan antara modal jangka panjang dengan modal sendiri. Penelitian ini bertujuan untuk menguji pengaruh struktur aset, profitabilitas, operating leverage dan likuiditas terhadap struktur modal. Pengukuran struktur modal dalam penelitian ini menggunakan long term debt to equity ratio (LTDER). Semakin tinggi tingkat presentase LTDER mengindikasikan bahwa semakin tinggi komposisi utang dibandingkan dengan modal sendiri perusahaan.Penelitian ini difokuskan pada perusahaan consumer goods yang terdaftar di Bursa Efek Indonesia (BEI) periode 2010-2014. Jumlah pengamatan sebanyak 100 sampel penelitian yang diperoleh dengan metode nonprobability sampling dengan teknik purposive sampling. Teknik analisis yang digunakan dalam penelitian ini adalah analisis regresi linear berganda. Hasil analisis menunjukkan bahwa struktur aset dan likuiditas berpengaruh positif terhadap struktur modal, profitabilitas dan operating leverage berpengaruh negatif terhadap struktur modal.
\end{abstract}

Kata Kunci: struktur modal, struktur aset, profitabilitas, operating leverage, dan likuiditas

\begin{abstract}
Capital structure is counter balance between capital eksternal (long-range) with the self capital. The purpose of this study to determine the effect of asset structure, profitability, operating leverage and likuiditas to capital structure. The measurement this study of capital structure use the long term debt to equity ratio (LTDER). Excelsior mount the presentase LTDER indication that excelsior of debt composition compared to a equity of a company. The study focussed at consumer goods company enlisted in Effect Exchange Indonesia (BEI) Period 2010-2014. Perception amount as much 100 sampel research obtained with the method of nonprobability sampling with the technique of purposive sampling. Analysis technique used in this study is multiple linear regression analysis. The result showed that asset structure and liquidty have a positive effect to capital structure, profitability and operating leverage have a negativity effect to capital structure.

Keyword: capital structure, asset structure, profitability, operating leverage, and liquidity
\end{abstract}


I Komang Yusa Dharmadi dan I Gusti Ayu Made Asri Dwija Putri. Pengaruh...

\section{PENDAHULUAN}

Perkembangan perekonomian di Indonesia khususnya pada sektor consumer goods sangat menarik untuk diteliti mengingat sektor consumer goods adalah salah satu sektor yang paling stabil dan diminati oleh para investor. Tingkat konsumsi dalam suatu wilayah sangat dipengaruhi oleh jumlah penduduk di wilayah tersebut. Melihat fenomena jumlah penduduk di Indonesia yang terus meningkat setiap tahunnya memberikan dampak terhadap semakin besarnya pangsa pasar serta semakin berkembangnya perusahaan-perusahaan consumer goods yang ada di Indonesia.

Perusahaan pada sektor consumer goods sama seperti perusahaan pada sektor-sektor lainnya membutuhkan dana untuk dapat mengembangkan dan mempertahankan kelangsungan hidupnya. Keputusan pendanaan merupakan keputusan tentang seberapa besar penggunaan utang dibandingkan ekuitas untuk pembiayaan dalam investasi (Sheikh dan Wang, 2011). Keterbatasan sumber pendanaan di dalam perusahaan menyebabkan perusahaan dalam melakukan pengembangan harus mencari alternatif permodalan lain yang berasal dari dana luar perusahaan (Supeno, 2009). Dalam menangani keterbatasan dana tersebut perusahaan diharapkan untuk lebih sigap, bijaksana serta lebih berhati-hati di dalam mencari pendanaan keuangan yang nantinya akan diperlukan dalam proses pembiayaan investasi perusahaan (Chandra, 2008)

Brigham dan Houston (2006:165) menyatakan penggunaan dana yang berasal dari utang mempunyai suatu kelebihan dan kelemahan, keunggulan dari utang yakni bunga yang dibayarkan perusahaan dapat mengurangi biaya pajak yang berdampak pada penurunan biaya efektif daripada utang itu sendiri, serta kreditur memperoleh pengembalian dengan jumlah tetap sehingga pemegang 
saham tidak harus membagi laba perusahaannya, sedangkan kelemahan dari utang yakni semakin besar jumlah utang pada komposisi struktur permodalan suatu perusahaan maka berdampak pada semakin tingginya risiko yang diterima perusahaan tersebut.

Riyanto (2008:296) menyatakan struktur modal adalah perimbangan antara modal eksternal (jangka panjang) dengan modal sendiri. Kemudian Bhattacharjee (2010) menyatakan struktur modal menunjukan perbandingan utang jangka panjang dengan ekuitas yang digunakan untuk pembiayaan aset. Saleem et al. (2013) menyatakan struktur modal berkaitan dengan perbedaan pilihan yang dipakai perusahaan untuk membiayai modalnya. Suatu perusahaan sangat penting untuk menentukan bagaimana komposisi yang baik dari struktur modal sehingga perusahaan dalam kegiatan operasional dan produksi dapat berjalan dengan baik dengan struktut modal yang optimal.

Masnoon and Saeed (2014) menyebutkan keputusan struktur modal adalah kunci utama keputusan keuangan dalam pembiayaan aset, kebangkrutan dan permasalahan perusahaan dapat saja terjadi apabila terjadi kesalahan dalam mempertimbangkan struktur modal. Modugu (2013) menyebutkan keberhasilan perusahaan di masa depan sangat bergantung kepada keputusan pemilihan struktur modal yang optimal dan menjadi tugas penting bagi pihak perusahaan. Pahuja and Sahi (2012) menyebutkan menyeimbangkan antara risiko dan keuntungan yang dicapai dapat digunakan dalam penentuan struktur modal yang optimal demi mencapai tujuan untuk meningkatkan harga saham. Brigham \& Houston (2006:168) menyebutkan trade off antara risiko dan tingkat pengembalian memiliki andil dalam kebijakan penentuan struktur modal. Menurut 
I Komang Yusa Dharmadi dan I Gusti Ayu Made Asri Dwija Putri. Pengaruh...

Myers (1984) Trade Off Theory sebagai penyeimbang manfaat dari pengorbanan yang timbul akibat dari penggunaan utang, penambahan jumlah utang dapat meningkatkan risiko akan tetapi sekaligus juga meningkatkan tingkat pengembalian.

Brigham \& Houston (2006:234) menyebutkan faktor struktur aset, tingkat pertumbuhan, pengendalian, sikap manajemen, leverage operasi, kondisi pasar, sikap pemberi pinjaman, profitabilitas, agen pemberi peringkat, pajak, kondisi internal perusahaan, stabilitas penjualan dan fleksibilitas keuangan sangat mempengaruhi penentuan keputusan struktur modal dari suatu perusahaan.

Dalam penelitian ini dipilih empat faktor untuk mengetahui apakah faktorfaktor tersebut memiliki pengaruh terhadap struktur modal suatu perusahaan. Keempat faktor tersebut adalah struktur aset, profitabilitas, operating leverage, dan likuiditas. Penelitian dilakukan pada perusahaan consumer goods yang terdaftar di Bursa Efek Indonesia dikarenakan melihat prospek perkembangan yang dimiliki pada sektor ini sangat baik. Selain itu laju pertumbuhan penduduk di Indonesia yang sangat pesat akan menyebabkan semakin besarnya pangsa pasar sehingga perusahaan-perusahaan ini memiliki potensi untuk terus mengembangkan perusahaan, yang tentu membutuhkan keputusan permodalan yang baik.

Menurut Houston dan Brigham (2006:232), struktur aset adalah besaran alokasi untuk komponen setiap aktiva yakni aktiva tetap dan aktiva tidak tetap. Sartono (2000:248) menyebutkan aset tetap yang besar dapat dipakai sebagai penjamin utang perusahaan sehingga perusahaan yang memiliki aset tetap dalam jumlah besar dapat mempergunakan utang dalam jumlah besar sesuai dengan 
kemampuan asetnya. Puspita dan Kusumaningtias (2010), Joni dan Lina (2010), Indrajaya,dkk. (2011), Srivastava (2014), Yusrianti (2013), Akhtar dan Masood (2013) jugaa menemukan bahwa struktur aset mempunyai hubungan positif terhadap struktur modal. Struktur aset berhubungan dengan banyaknya aset yang dapat dipergunakan sebagai jaminan kepada debitur, peluang suatu perusahaan untuk memperoleh dan menggunakan utang semakin besar apabila struktur aset yang dimiliki suatu perusahaan dalam jumlah besar yang nantinya dipergunakan sebagai jaminan utang tersebut. Kreditur akan lebih yakin terhadap perusahaan yang mempunyai aset tetap yang besar karena apabila terjadi kegagalan pembayaran maka perusahaan dapat menyelesaikan kewajibannya kepada kreditur dengan jaminan asetnya tersebut. Dengan demikian, dapat diprediksikan struktur aset memiliki hubungan yang positif terhadap struktur modal.

$\mathrm{H}_{1}$ : Struktur aset berpengaruh positif terhadap struktur modal.

Riyanto (2008:35) menyatakan profitabilitas mempunyai arti kemampuan perusahaan dalam memperoleh laba atau keuntungan selama periode tertentu. Myers and Majluf (1984) menyatakan pecking order theory menjelaskan bahwa perusahaan dengan kemampuan menghasilkan profit yang tinggi dapat mempergunakan dana dari dalam internal perusahaannya terlebih dahulu sebelum perusahaan memilih untuk mempergunakan utang untuk pemenuhan kebutuhan pendanaan perusahaan itu sendiri. Teori ini sejalan dengan penelitian yang telah dilakukan oleh Febriyani dan Srimindarti (2010), Joni dan Lina (2010), Indrajaya., dkk (2011), Wardani (2011), Baharuddin, et al. (2011), Santika dan Sudiyatno (2011), Mishra (2011), Alom (2013), Sudibya (2011), Dewi dan Badjra (2014), 
I Komang Yusa Dharmadi dan I Gusti Ayu Made Asri Dwija Putri. Pengaruh...

Mardiansyah (2013) dan Sari (2014) yang menunjukan bahwa profitabilitas memiliki pengaruh negatif terhadap struktur modal. Dengan demikian perusahaan yang memiliki tingkat profitabilitas yang tinggi akan mengurangi ketergantungannya pada pihak eksternal perusahaan karena profit perusahaan yang tinggi memungkinkan perusahaan untuk mendanai perusahaannya sendiri melalui laba ditahan. Sehingga dapat diprediksikan bahwa profitabilitas memiliki hubungan negatif terhadap struktur modal.

$\mathrm{H}_{2}$ : Profitabilitas berpengaruh negatif terhadap struktur modal.

Operating leverage memiliki pengaruh negatif terhadap struktur modal, semakin tinggi tingkat operating leverage maka akan semakin rendah tingkat utang perusahaan tersebut. Dengan keputusan mempertahankan struktur modal maka perusahaan tidak akan terlalu bergantung lagi pada pihak eksternal karena penggunaan utang yang berkaitan dengan risiko perusahaan (Sudiyatno, 2011:178).

Hal ini disebabkan operating leverage merupakan seberapa besar penggunaan dana dari eksternal perusahaan yakni dari pinjaman yang digunakan dalam operasi suatu perusahaan. Perusahaan berharap dengan menggunakan operating leverage maka perubahan penjualan akan menghasilkan perubahan pada laba sebelum bunga dan pajak yang lebih besar. Operating leverage akan dapat menguntungkan bagi perusahaan apabila pendapatan perusahaan setelah dikurangi biaya variabel lebih besar dari biaya tetapnya (Brigham \& Houston, 2006:235). Maka semakin rendah biaya tetap yang dipergunakan oleh perusahaan maka akan berdampak pada penghasilan laba yang semakin besar. Dengan memperoleh laba 
yang besar maka perusahaan dapat membiayai pendanaannya dengan dana yang dihasilkan di internal perusahaan itu sendiri sehingga akan menyebabkan semakin rendahnya kemungkinan pendanaan dari eksternal perusahaan (hutang). Ini sejalan dengan teori pecking order yang menyatakan bahwa perusahaan lebih menyukai pendanaan dari dalam internal perusahaan dibandingkan melakukan utang. Teori ini sejalan dengan penelitian yang telah dilakukan oleh Winahyuningsih, dkk (2010) dan Nugroho (2006). Sehingga dapat diprediksikan bahwa operating leverage memiliki hubungan negatif terhadap struktur modal.

$\mathrm{H}_{3}$ : Operating leverage berpengaruh negatif terhadap struktur modal.

Riyanto (2008:25) menyebutkan likuiditas berhubungan dengan kemampuan perusahaan dalam memenuhi kewajibannya yakni kewajiban finansial yang berjangka pendek tepat pada waktunya. Implikasi dari trade-off models menyatakan bahwa perusahaan yang memenuhi kewajiban pengembalian utang-utangnya tepat pada waktunya akan mendapatkan kepercayaan yang lebih tinggi dari kreditur. Kreditur akan lebih yakin dalam menyalurkan modalnya dengan melihat dari tingkat likuiditas perusahaan tersebut, kemudian bagi perusahaan yang telah mendapat pinjaman dana akan memanfaatkan kesempatan tersebut dengan baik untuk mengembangkan perusahaannya (Rachmawardani, 2007). Sehingga dapat diprediksi bahwa likuditas memiliki pengaruh positif terhadap struktur modal.

$\mathrm{H}_{4}$ : Likuiditas berpengaruh positif terhadap struktur modal. 
I Komang Yusa Dharmadi dan I Gusti Ayu Made Asri Dwija Putri. Pengaruh...

\section{METODE PENELITIAN}

Lokasi penelitian dilakukan pada perusahaan consumer goods yang terdaftar di Bursa Efek Indonesia pada tahun 2010-2014. Obyek pada penelitian ini adalah struktur modal pada perusahaan consumer goods. Dalam penelitian ini struktur modal menjadi variabel yang terikat sedangkan variabel bebas digunakan adalah struktur aset $\left(X_{1}\right)$, profitabilitas $\left(X_{2}\right)$, operating leverage $\left(X_{3}\right)$, dan likuiditas $\left(X_{4}\right)$.

Riyanto (2008:333) menyatakan struktur modal dapat diukur dengan menggunakan long term debt to equity ratio.

Long Term Debt to Equity Ratio= $\frac{\text { Utang Jangka Panjang }}{\text { Modal Sendiri }} \times 100 \%$

Struktur aset adalah perimbangan atau perbandingan antara aset tetap dan total aset (Weston dan Copeland, 2008:175).

Struktur Aset $=\frac{\text { Aset Tetap }}{\text { Total Aset }} \times 100 \%$

Riyanto (2008:336) menyatakan profitabilitas dapat diukur dengan menggunakan return on investment yakni perbandingan antara laba bersih setelah pajak dengan jumlah aset.

Return on investment $=\frac{\text { Laba Bersih Setelah Pajak }}{\text { Jumlah Aset }} \times 100 \%$

Brigham dan Houston (2006:188) operating leverage dapat diukur dengan menggunakan degree of operating leverage (DOL).

Degree of Operating Leverage $=\frac{\% \text { Perubahan EBIT }}{\% \text { Perubahan penjualan }}$.

Riyanto (2008:26) menyatakan likuiditas dapat diukur dengan menggunakan current ratio yakni perbandingan aset lancar dengan utang lancar.

Current Ratio $=\frac{\text { Aset Lancar }}{\text { Utang Lancar }} \times 100 \%$ 
Populasi perusahaan consumer goods yakni berjumlah 37 perusahaan dan perusahaan yang akan dijadikan sampel penelitian adalah 20 perusahaan. Penentuan sampel menggunakan metode nonprobability sampling dengan teknik purposive sampling. sedangkan metode dalam pengumpulan data menggunakan observasi non participant, yakni dengan membaca, mengumpulkan, mencatat data informasi serta keterangan namun peneliti tidak terlibat langsung dan hanya mengamati secara independen. Teknik analisis data yang digunakan adalah regresi linear berganda dengan mempergunakan program SPSS (statistical product and service solution). Teknik ini dipergunakan untuk melihat pengaruh keempat variabel yakni struktur aset, profitabilitas, operating leverage dan likuiditas terhadap struktur modal. Tahap analisis yang dilakukan dalam penelitian ini antara lain, statistik deskriptif, uji asumsi klasik, analisis regresi linear berganda, koefisien determinasi, uji F, dan uji t.

\section{HASIL DAN PEMBAHASAN}

Deskripsi variabel penelitian menyajikan data tentang karakteristik variabelvariabel penelitian, yang terdiri dari jumlah pengamatan, nilai minimum, nilai maksimum, nilai rata-rata, serta standar deviasi. Tabel 1. memperlihatkan hasil uji statistik deskriptif sebagai berikut.

Tabel 1.

Hasil Uji Statistik Deskriptif

\begin{tabular}{|l|r|r|r|r|r|}
\hline \multicolumn{1}{|c|}{ Variabel } & $\begin{array}{c}\text { Jumlah } \\
\text { Sampel }\end{array}$ & $\begin{array}{c}\text { Nilai } \\
\text { Minimum }\end{array}$ & $\begin{array}{c}\text { Nilai } \\
\text { Maksimum }\end{array}$ & $\begin{array}{c}\text { Nilai } \\
\text { Rata- } \\
\text { Rata }\end{array}$ & $\begin{array}{c}\text { Standar } \\
\text { Deviasi }\end{array}$ \\
\hline Struktur aset & 100 & 0,14 & 1,25 & 0,4390 & 0,20256 \\
\hline Profitabilitas & 100 & 0,02 & 1,42 & 0,4457 & 0,27946 \\
\hline Operating leverage & 100 & 0,59 & 3,82 & 2,1539 & 0,46298 \\
\hline Likuiditas & 100 & 0,73 & 2,78 & 1,1723 & 0,41476 \\
\hline Struktur modal & 100 & 0,02 & 1,38 & 0,1999 & 0,24024 \\
\hline
\end{tabular}

Sumber: Data diolah, 2015 
I Komang Yusa Dharmadi dan I Gusti Ayu Made Asri Dwija Putri. Pengaruh...

Variabel bebas struktur aset memiliki nilai rata-rata sebesar 0,4390 dengan standar deviasi sebesar 0,20256. Nilai rata-rata variabel profitabilitas perusahaan sebesar 0,4457 dengan standar deviasi yaitu sebesar 0,27946. Variabel bebas operating leverage memiliki nilai rata-rata sebesar 2,1539 dengan standar deviasi sebesar 0,46298. Nilai rata-rata variabel bebas likuiditas sebesar 1,1723 dengan standar deviasi yaitu sebesar 0,41476. Struktur modal yang diproksikan melalui long term debt to equity ratio pada perusahaan consumer goods yang terdaftar di Bursa Efek Indonesia pada tahun 2010-2014 rata-rata sebesar 0,1999 dengan standar deviasi sebesar 0,24024.

Hasil Uji Asumsi Klasik

Hasil uji asumsi klasik disajikan dalam Tabel 2. di bawah ini.

Tabel 2.

Hasil Uji Asumsi Klasik

\begin{tabular}{|l|c|c|c|c|c|}
\hline \multirow{2}{*}{$\begin{array}{c}\text { Parameter yang } \\
\text { Diuji }\end{array}$} & $\begin{array}{c}\text { Uji } \\
\text { Normalitas }\end{array}$ & \multicolumn{2}{|c|}{$\begin{array}{c}\text { Uji } \\
\text { Multikolinearitas }\end{array}$} & $\begin{array}{c}\text { Uji } \\
\text { Heteros } \\
\text { Kedastisitas }\end{array}$ & $\begin{array}{c}\text { Uji } \\
\text { Auto } \\
\text { Korelasi }\end{array}$ \\
\cline { 2 - 6 } & $\begin{array}{c}\text { Asymp. Sig. } \\
\text { (2-tailed) }\end{array}$ & Tolerance & VIF & Sig. & DW \\
\hline $\begin{array}{l}\text { Unstandardized } \\
\text { Residual }\end{array}$ & 0,162 & & & & \\
\hline Struktur asset & & 0,174 & 5,746 & 0,778 & \\
\hline Profitabilitas & & 0,733 & 1,363 & 0,269 & \\
\hline Operating leverage & & 0,194 & 5,150 & 0,635 & \\
\hline Likuiditas & & 0,587 & 1,703 & 0,489 & \\
\hline Durbin-Watson & & & & & 1,973 \\
\hline
\end{tabular}

Sumber: Data diolah, 2015

Uji Normalitas

Berdasarkan Tabel 2. diketahui bahwa nilai Sig (2-tailed) sebesar 0,162 lebih besar dari tingkat signifikansi (level of significant) yaitu sebesar 0,05 (5\%). Hasil pengujian menunjukkan bahwa data yang dianalisis telah terdistribusi secara normal. 
Uji Multikolinearitas

Berdasarkan Tabel 2. diketahui bahwa nilai tolerance setiap variabel bebas lebih besar dari $10 \%$ dan nilai VIF kurang dari 10, sehingga dapat diambil kesimpulan bahwa variabel bebas tidak saling berkorelasi secara signifikan. Hasil pengujian ini menunjukkan bahwa data yang dianalisis telah memenuhi asumsi multikolinearitas.

Uji Heteroskedastisitas

Berdasarkan Tabel 2. dapat diketahui bahwa tingkat signifikansi keempat variabel diatas $5 \%$ atau 0,05 . Hasil pengujian ini menunjukkan model regresi yang ada telah terbebas dari masalah heteroskedastisitas.

Uji Autokorelasi

Berdasarkan Tabel 2. nilai DW sebesar 1,973. Nilai $d_{u}$ untuk jumlah sampel (N) sebanyak 100 dengan jumlah variabel bebas (k) sebesar 4 adalah 1,7582, maka nilai 4 - duyang didapat adalah 2,2418. Hasil uji autokorelasinya adalah $\mathrm{d}_{\mathrm{U}}<\mathrm{DW}$ $<4-\mathrm{d}_{\mathrm{U}}$ yaitu $1,7582<1,973<2,2418$. Hasil tersebut menunjukkan bahwa data telah bebas autokorelasi.

Hasil Uji Analisis Regresi Linear Berganda

Tabel 3. menunjukkan hasil pengujian regresi linear berganda dengan tingkat signifikansi sebesar 5\%.

Tabel 3.

Hasil Uji Analisis Regresi Linear Berganda

\begin{tabular}{|l|c|c|}
\hline \multicolumn{1}{|c|}{ Variabel } & \multirow{2}{*}{ Nilai Beta } & Signifikansi \\
\hline Uji Statistik t & & 0,259 \\
\hline (Constant) & 0,154 & 0,000 \\
\hline Struktur aset & 0,769 & \\
\hline
\end{tabular}


I Komang Yusa Dharmadi dan I Gusti Ayu Made Asri Dwija Putri. Pengaruh...

\begin{tabular}{|l|c|c|}
\hline Profitabilitas & $-0,425$ & 0,000 \\
\hline Operating leverage & $-0,183$ & 0,040 \\
\hline Likuiditas & 0,248 & 0,000 \\
\hline Uji Statistik F & \\
\hline Nilai F & \multicolumn{2}{|c|}{21,331} \\
\hline Sig. & 0,000 \\
\hline Uji Koefisien Determinasi & \\
\hline Adjusted $R$ Square & 0,451 \\
\hline Dependen var. struktur modal & \\
\hline
\end{tabular}

Sumber: Data diolah, 2015

Berdasarkan Tabel 3. diperoleh persamaan regresi sebagai berikut.

$\mathrm{Y}=\alpha+\beta_{1} \mathrm{X}_{1}+\beta_{2} \mathrm{X}_{2}+\beta_{3} \mathrm{X}_{3}+\beta_{4} \mathrm{X}_{4}+\mathrm{e}$

$\mathrm{Y}=0,154+0,769 \mathrm{X}_{1}-0,425 \mathrm{X}_{2}-0,183 \mathrm{X}_{3}+0,248 \mathrm{X}_{4}$

Persamaan diatas memperlihatkan bahwa nilai konstanta sebesar 0,154 yang mempunyai arti jika semua variabel bebas struktur aset, profitabilitas, operating leverage, dan likuiditas konstan, mengakibatkan nilai dari struktur modal adalah sebesar 0,154 . Koefisien struktur aset 0,769 mempunyai arti bahwa apabila struktur aset meningkat $1 \%$ menyebabkan struktur modal meningkat sebesar 0,769 dengan mengasumsikan faktor lainnya konstan. Koefisien profitabilitas sebesar $-0,425$ mempunyai arti bahwa apabila profitabilitas meningkat $1 \%$ maka akan menyebabkan struktur modal menurun sebesar 0,425 dengan mengasumsikan faktor lainnya konstan. Koefisien operating leverage sebesar -0,183 memiliki arti bahwa apabila operating leverage meningkat $1 \%$ akan menyebabkan struktur modal menurun sebesar 0,183 dengan mengasumsikan faktor lainnya konstan. Koefisien likuiditas sebesar 0,248 mempunyai arti bahwa apabila likuiditas meningkat $1 \%$ maka akan menyebabkan 
struktur modal meningkat sebesar 0,248 dengan mengasumsikan faktor lainnya konstan.

Hasil Uji Koefisien Determinasi (Adjusted $R^{2}$ )

Tabel 3. menunjukkan angka koefisien determinasi sebesar 0,451. Ini berarti bahwa $45,1 \%$ variasi struktur modal dapat dijelaskan oleh variasi dari ke empat variabel independen yaitu struktur aset, profitabilitas, operating leverage, dan likuiditas. Sisanya sebesar 54,9\% dijelaskan oleh variabel lain di luar penelitian. Hasil Uji Kelayakan Model (Uji F)

Berdasarkan Tabel 3. dapat dilihat bahwa hasil perhitungan dari uji $\mathrm{F}$ memperlihatkan signifikansi sebesar $0,000<0,05$. Ini berarti model dapat dikatakan layak untuk menguji variabel independen terhadap variabel dependen. Hasil Uji t

Tabel 3. memperlihatkan bahwa keempat variabel memiliki pengaruh terhadap struktur modal yakni struktur aset, profitabilitas, operating leverage dan likuiditas. Hal ini dapat dilihat dari nilai probabilitas signifikansi untuk struktur aset sebesar 0,000 $(\alpha<0,05)$, profitabilitas sebesar 0,000 ( $\alpha<0,05)$, operating leverage sebesar 0,040 $(\alpha<0,05)$, dan likuiditas sebesar 0,000 $(\alpha<0,05)$. Jadi dapat diambil kesimpulan bahwa variabel struktur aset, profitabilitas, operating leverage, dan likuiditas memiliki pengaruh terhadap variabel struktur modal.

Berdasarkan hasil pengujian hipotesis pertama (H1), memperlihatkan bahwa nilai koefisien positif sebesar 0,769 dengan tingkat signifikansi 0,000 yang lebih rendah dari taraf nyata dalam penelitian ini yaitu $\alpha=0,05$. Hal ini memperlihatkan bahwa struktur aset berpengaruh positif terhadap struktur modal. 
I Komang Yusa Dharmadi dan I Gusti Ayu Made Asri Dwija Putri. Pengaruh...

Sehingga hipotesis pertama $\left(\mathrm{H}_{1}\right)$ dapat diterima yaitu struktur aset berpengaruh positif terhadap struktur modal dimana semakin besar struktur aset maka semakin tinggi struktur modal di dalam suatu perusahaan. Puspita dan Kusumaningtias (2010), Joni dan Lina (2010), Indrajaya,dkk. (2011), Srivastava (2014), Yusrianti (2013), Akhtar dan Masood (2013) menemukan bahwa struktur aset mempunyai hubungan positif terhadap struktur modal. Struktur aset berhubungan dengan banyaknya aset yang dapat dipergunakan sebagai jaminan kepada debitur, peluang suatu perusahaan untuk memperoleh dan menggunakan utang semakin besar apabila struktur aset yang dimiliki suatu perusahaan dalam jumlah besar yang nantinya dipergunakan sebagai jaminan utang tersebut. Kreditur akan lebih yakin terhadap perusahaan yang mempunyai aset tetap yang besar karena apabila terjadi kegagalan pembayaran bayar maka perusahaan dapat menyelesaikan kewajibannya kepada kreditur dengan jaminan asetnya tersebut.

Berdasarkan hasil pengujian hipotesis kedua $\left(\mathrm{H}_{2}\right)$, menunjukkan bahwa nilai koefisien sebesar -0,425 dengan tingkat signifikansi 0,000 yang lebih kecil dari taraf nyata dalam penelitian ini yaitu $\alpha=0,05$. Hal ini memperlihatkan bahwa profitabilitas berpengaruh negatif terhadap struktur modal. Sehingga hipotesis kedua $\left(\mathrm{H}_{2}\right)$ dapat diterima yaitu profitabilitas berpengaruh negatif terhadap struktur modal dimana semakin tinggi tingkat profitabilitas perusahaan maka struktur modal perusahaan akan semakin rendah. Pecking order theory menjelaskan bahwa perusahaan dengan kemampuan menghasilkan profit yang tinggi dapat mempergunakan dana dari dalam internal perusahaannya terlebih dahulu sebelum perusahaan memilih untuk mempergunakan utang dalam pemenuhan kebutuhan pendanaan perusahaan. Teori ini sejalan dengan penelitian 
yang dilakukan oleh Febriyani dan Srimindarti (2010), Joni dan Lina (2010), Indrajaya., dkk (2011), Wardani (2011), Baharuddin, et al. (2011), Santika dan Sudiyatno (2011), Mishra (2011), Alom (2013), Sudibya (2011), Dewi dan Badjra (2014), Mardiansyah (2013) dan Sari (2014) yang menunjukan bahwa profitabilitas memiliki pengaruh negatif terhadap struktur modal. Dengan demikian perusahaan yang memiliki tingkat profitabilitas yang tinggi akan mengurangi ketergantungannya pada pihak eksternal perusahaan karena profit perusahaan yang tinggi memungkinkan perusahaan untuk mendanai perusahaannya sendiri melalui laba ditahan.

Berdasarkan hasil pengujian hipotesis ketiga $\left(\mathrm{H}_{3}\right)$, menunjukkan bahwa nilai koefisien negatif sebesar -0,183 dengan tingkat signifikansi 0,040 yang lebih kecil dari taraf nyata dalam penelitian ini yaitu $\alpha=0,05$. Hal ini menunjukkan bahwa operating leverage berpengaruh negatif terhadap struktur modal. Sehingga hipotesis ketiga $\left(\mathrm{H}_{3}\right)$ dapat diterima yaitu operating leverage berpengaruh negatif terhadap struktur modal dimana semakin tinggi operating leverage maka struktur modal perusahaan semakin menurun. Dengan kebijakan mempertahankan struktur modal maka perusahaan bisa meminimalisir akan penggunaan utang yang terkait dengan risiko yang akan dialami oleh perusahaan (Sudiyatno, 2011:178).

Hal ini disebabkan operating leverage merupakan seberapa besar penggunaan dana dari eksternal perusahaan yakni dari pinjaman yang digunakan dalam operasi suatu perusahaan. Perusahaan berharap dengan menggunakan operating leverage maka perubahan penjualan akan menghasilkan perubahan pada laba sebelum bunga dan pajak yang lebih besar. Operating leverage akan dapat 
I Komang Yusa Dharmadi dan I Gusti Ayu Made Asri Dwija Putri. Pengaruh...

menguntungkan bagi perusahaan apabila pendapatan perusahaan setelah dikurangi biaya variabel lebih besar dari biaya tetapnya (Brigham \& Houston, 2006:235). Maka semakin rendah biaya tetap yang dipergunakan oleh perusahaan maka akan berdampak pada penghasilan laba yang semakin besar. Dengan memperoleh laba yang besar maka perusahaan dapat membiayai pendanaannya dengan dana yang dihasilkan di internal perusahaan itu sendiri sehingga akan menyebabkan semakin rendahnya kemungkinan pendanaan dari eksternal perusahaan (hutang). Ini sejalan dengan teori pecking order yang menyatakan bahwa perusahaan lebih menyukai pendanaan dari dalam internal perusahaan dibandingkan melakukan utang. Teori ini sejalan dengan penelitian yang telah dilakukan oleh Winahyuningsih, dkk (2010) dan Nugroho (2006).

Berdasarkan hasil pengujian hipotesis keempat $\left(\mathrm{H}_{4}\right)$, menunjukkan bahwa nilai koefisien positif sebesar 0,248 dengan tingkat signifikansi 0,000 yang lebih kecil dari taraf nyata dalam penelitian ini yaitu $\alpha=0,05$. Hal ini menunjukkan bahwa likuiditas berpengaruh positif terhadap struktur modal. Sehingga hipotesis keempat $\left(\mathrm{H}_{4}\right)$ dapat diterima yaitu likuiditas berpengaruh positif terhadap struktur modal dimana semakin tinggi likuiditas perusahaan maka semakin tinggi struktur modal perusahaan. Implikasi dari trade-off models menyatakan bahwa perusahaan yang memenuhi kewajiban pengembalian utang-utangnya tepat pada waktunya akan mendapatkan kepercayaan yang lebih tinggi dari kreditur. Kreditur akan lebih yakin dalam menyalurkan modalnya dengan melihat dari tingkat likuiditas perusahaan tersebut, kemudian bagi perusahaan yang telah mendapat pinjaman dana akan memanfaatkan kesempatan tersebut dengan baik untuk 
mengembangkan perusahaannya (Rachmawardani, 2007). Teori ini sejalan dengan penelitian yang dilakukan oleh Liwang (2011), Sabir dan Malik (2012), Naibaho (2013) yang hasil penelitiaannya membuktikan bahwa likuiditas berpengaruh positif terhadap struktur modal.

\section{SIMPULAN}

Berdasarkan hasil analisis dan pembahasan dapat mengambil kesimpulan bahwa struktur aset berpengaruh positif terhadap struktur modal yang memiliki arti semakin besar struktur aset perusahaan maka semakin tinggi pula struktur modal perusahaan. Profitabilitas berpengaruh negatif terhadap struktur modal artinya semakin tinggi profitabilitas perusahaan maka struktur modal perusahaan akan semakin rendah. Operating leverage berpengaruh negatif terhadap struktur modal yang memiliki arti semakin tinggi operating leverage maka struktur modal perusahaan akan semakin rendah. Likuiditas berpengaruh positif terhadap struktur modal yang memiliki arti semakin tinggi tingkat likuiditas maka semakin tinggi pula struktur modal perusahaan.

Berdasarkan hasil penelitian dan simpulan yang telah dilakukan saran yang dapat disampaikan adalah bagi manajemen perusahaan diharapkan dapat lebih memperhatikan setiap keputusan yang akan diambil dalam berutang serta risiko yang akan diterima terkait dengan kebijakan struktur modalnya. Penelitian ini dapat digunakan sebagai bahan pertimbangan dalam menentukan sumber pendanaan yang paling sesuai dengan perusahaan dalam usaha mengembangkan bisnisnya, perusahaan harus menentukan besarnya jumlah perbandingan pinjaman dengan modal sendiri agar struktur modal yang dimiliki perusahaan bisa mencapai 
yang paling optimal, yakni dengan memperhatikan faktor seperti struktur aset, profitabilitas, operating leverage dan likuiditas.

Nilai koefisien korelasi positif berarti apabila variabel independen naik, variabel dependen akan naik juga, jadi apabila dalam komposisi struktur modal perusahaan ternyata komposisi hutangnya masih kurang maka perusahaan sebaiknya memperbaiki faktor yang mempunyai korelasi positif dengan struktur modal sehingga jumlah hutang yang sebelumnya masih jauh dari jumlah optimal dapat diperbaiki untuk diposisikan agar paling mendekati struktur modal yang optimal, begitu pun sebaliknya apabila komposisi modal sendiri masih kurang dalam komposisi struktur modal yang optimal maka perusahaan sebaiknya memperbaiki nilai dari faktor yang mempunyai korelasi negatif dengan struktur modal sehingga komposisi modal sendiri dalam struktur modal dapat mencapai yang paling optimal atau paling tidak sudah mendekati struktur modal yang optimal.

Bagi kreditur hasil penelitian menunjukkan bahwa variabel struktur aset, profitabilitas, operating leverage dan likuiditas yang diteliti berpengaruh terhadap struktur modal pada perusahaan. Sehingga variabel tersebut dapat dijadikan sebagai salah satu bahan pertimbangan bagi kreditur sebelum menyalurkan pinjaman pada perusahaan.

Bagi Akademisi penelitian ini memiliki keterbatasan yang perlu diperbaiki pada penelitian selanjutnya. Penelitian ini hanya mempergunakan 4 faktor yang mempengaruhi struktur modal dari sekian banyak faktor yang mempengaruhi struktur modal. Penelitian ini juga terbatas pada lingkup perusahaan consumer 
goods di Bursa Efek Indonesia sebagai populasi, sehingga belum mampu merepresentasikan seluruh perusahaan yang terdaftar di Bursa Efek Indonesia. Saran yang dapat peneliti sampaikan pada peneliti selanjutnya adalah menambah faktor-faktor yang mempengaruhi struktur modal sehingga dapat melengkapi hasil penelitian terdahulu serta menambah lingkup populasi penelitian tidak hanya pada perusahaan sektor consumer goods saja tetapi juga pada sektor-sektor yang lain.

\section{REFERENSI}

Akhtar, Pervez., and Sabeen Masood. 2013. Analysis of Capital Structure Determinant A case from Pakistan's chemical sector companies listed at Karachi stock exchange. International Journal of Business and Social Research (IJBSR), 3(5), pp: 43-49.

Alom, Khairul. 2013. Capital Structure Choice of Bangladesh Firms: An Empirical Investigation. Asian Journal of Finance \& Accounting, 5(1), pp: 320-333.

Baharuddin, Nurul Syuhada., Zaleha Khamis, Wan Mansor Wan Mahmood, and Hussian Dollah. 2011. Determinants of Capital Structure for Listed Construction Companies in Malaysia. Journal of Applied Finance \& Banking, 1(2). pp: 115-132.

Bhattacharjee, Bidyut Jyoti. 2010. Capital Structure Decision: An Empirical Investigation In Indian Information Technology Sector. Journal of Business Management Studies, 6(2), pp: 18-24.

Brigham, Eugene F. dan Joel F. Houston. 2006. Dasar-Dasar Manajemen Keuangan (1). Edisi 10. Jakarta: Salemba Empat.

Chandra, Teddy. 2008. Analisis tentang Struktur Modal Perusahaan di Bursa Efek Jakarta. Jurnal Eksekutif, 5 (2), h:393-400.

Dewi, Ni Kadek Sugiani Merta., dan Ida Bagus Badjra. 2014. Pengaruh Likuiditas, Profitabilitas, Tangibility Assets, Ukuran Perusahaan Dan Pajak Terhadap Struktur Modal. E-Jurnal Manajemen Universitas Udayana,3(10), h: 13-28.

Febriyani, Nina., dan Ceacilia Srimindarti. 2010. Faktor-Faktor Yang Mempengaruhi Struktur Modal Pada Perusahaan Perusahaan LQ-45 di 
I Komang Yusa Dharmadi dan I Gusti Ayu Made Asri Dwija Putri. Pengaruh...

Bursa Efek Indonesia Periode 2006-2008. Jurnal Dinamika Keuangan dan Perbankan, 2(2), h:138-159.

Indrajaya, Glenn., Herlina., dan Setiadi Rini. 2011. Pengaruh Struktur Aset, Ukuran Perusahaan, Tingkat Pertumbuhan, Profitabilitas dan Risiko Bisnis

Terhadap Struktur Modal: Studi Empiris Pada Perusahaan Sektor Pertambangan yang Listing di Bursa Efek Indonesia Periode 2004-2007. Akurat Jurnal Ilmiah Akuntansi, 6(2). h: 1-23.

Joni dan Lina. 2010. Faktor-Faktor yang Mempengaruhi Struktur Modal. Jurnal Bisnis dan Akuntansi, 12(2), h: 81-96.

Liwang, Florencia Paramitha. 2011. Analisis Faktor-Faktor Yang Mempengaruhi Struktur Modal Dan Pengaruhnya Terhadap Harga Saham Pada PerusahaanPerusahaan Yang Tergabung Dalam LQ-45 periode 2006-2009. Seminar Nasional Teknologi Informasi \& Komunikasi Terapan 2011 (Semantik 2011) ISBN 979-26-0255-0, h: 26-33.

Mardiansyah, Tommy. 2013. Pengaruh Profitabilitas dan Operating Leverage Terhadap Struktur Modal Pada Perusahaan Makanan dan Minuman yang Terdaftar di Bursa Efek Indonesia (BEI) Tahun 2008-2011. E-jurnal-UNP, 2(1), h: 73-81.

Masnoon, Maryam., and Abiha Saeed. 2014. Capital Structure Determinants Of Kse Listed Automobile Companies. Scientific Journal, 10(13), pp: 451-461.

Mishra, Chandra Sekar. 2011. Determinants of Capital Structure-A Study of Manufacturing Sector PSUs in India. International Conference on Financial Management and Economics, 11, pp: 247-252.

Modugu, Kennedy Prince. 2013. Capital Structure Decision: An Overview. Journal of Finance and Bank Management, Vol 1(1), pp:14-27.

Myers, S. C. and N. S. Majluf. 1984. Corporate Financing and Investment Decisions When Firms Have Information That Investors Do Not Have, Journal of Financial Economics, 13, pp. 187-221.

Naibaho, Natalia. 2013. Pengaruh Profitabilitas, Likuiditas, Dan Modal Kerja Terhadap Struktur Modal Pada Perusahaan Manufaktur Meliputi Sektor Aneka Industri Dan Sektor Industri Barang Konsumsi Yang Terdaftar Di Bursa Efek Indonesia. Skripsi. Departement Akuntansi Fakultas Ekonomi Universitas Sumatera Utara, Medan.

Nugroho, Asih, Suko. 2006. Analisis Faktor-Faktor Yang Mempengaruhi Struktur Modal Perusahaan Properti Yang Go-Public Di Bursa Efek Jakarta Untuk 
Periode Tahun 1994 - 2004. Tesis Program Studi Magister Manajemen Universitas Diponogoro Semarang.

Pahuja, Anurag., and Anus Sahi. 2012. Factors Affecting Capital Structure Decision: Empirical Evidence From Selected Indian Firms. International Journal of Marketing, Financial Service, \& Management Research, 1(3), ISSN 2277-3622.

Puspita, Gita Cahya., dan Rohmawati Kusumaningtias. 2010. Pengaruh Struktur Aktiva, Profitabilitas, Kebijakan Dividen Terhadap Struktur Modal Pada Perbankan Yang Terdaftar di Bursa Efek Indonesia Pada Tahun 2005-2009. Jurnal Akuntansi, 2 (1), h: 70-84.

Rachmawardani, Yulinda. 2007. Analisis Pengaruh Aspek Likuiditas, Risiko Bisnis, Profitabilitas, Dan Pertumbuhan Penjualan Terhadap Struktur Modal Perusahaan (Studi empiris pada sector keuangan dan perbankan di BEJ tahun 2000-2005). Tesis, Universitas Diponegoro, Semarang.

Riyanto, Bambang. 2008. Dasar-Dasar Pembelanjaan Perusahaan. Edisi 4. Yogyakarta: BPFE.

Sabir, Mahvish and Qaisar Ali Malik. 2012. Determinants of Capital Structure -A Study of Oil and Gas Sector of Pakistan. Interdisciplinary Journal Of Contemporary Research In Business, 3(10), pp: 395-400.

Saleem, Faiza., Bisma Rafique, Qaiser Mehmood, Muhammad Irfan, Rabia Saleem, Sidra Tariq, and Ghazala Akram. 2013. The Determinants of Capital Structure of Oil and Gas Firms Listed on Karachi stock Exchange In Pakistan. Interdisciplinary Journal of Contemporary Research In Business, 4(9): pp: 225-235.

Santika, Rista Bagus Dan Bambang Sudiyatno. 2011. Menentukan Struktur Modal Perusahaan Manufaktur Di Bursa Efek Indonesia. Dinamika Keuangan danPerbankan, 3(2), h: 172-182.

Sari, Ni Putu Ayu Pudak. 2014. Faktor-Faktor Yang Memengaruhi Struktur Modal Pada Perusahaan Non Keuangan Yang Terdaftar Di Bursa Efek Indonesia Tahun 2008-2012. E-Jurnal Akuntansi Universitas Udayana, 7(1), h: 33-47.

Sartono, Agus. 2000. Manajemen Keunagan Teori dan Aplikasi. Edisi Empat. Yogyakarta: BPFE.

Sheikh, Nadeem Ahmed, and Zongjun Wang. 2011. Determinant of Capital Structure An Empirical Study of Firms in Manufacturing Industry of Pakistan. Managerial Finance, 37 (2), pp: 117-133. 
I Komang Yusa Dharmadi dan I Gusti Ayu Made Asri Dwija Putri. Pengaruh...

Srivastava, Namita. 2014. Determinants of leverage of Indian companies: An empirical analysis (A study of Cement Industry in India). Merit Research Journal of Art, Social Science and Humanities, Vol 2(2), pp: 21-24.

Sudibya, Nadia Anandari. 2011. Pengaruh Struktur Aset, Profitabilitas Dan Struktur kepemilikan Terhadap Struktur Modal Pada Perusahaan Consumer Goods Industry Yang Terdaftar Di PT. Bursa Efek Indonesia (BEI) periode 2007-2010. Skripsi. Fakultas Ekonomi Universitas Udayana, Denpasar.

Sudiyatno, B. 2011. Menentukan Struktur Modal Perusahaan Manufaktur di Bursa Efek Indonesia. Jurnal Ilmu Manajemen, 3. 172-182.

Supeno, Bambang. 2009. Analisis Faktor-faktor yang Mempengaruhi Struktur Modal Perusahaan Sektor Makanan dan Minuman pada Bursa Efek Jakarta (BEJ). Jurnal Tepak Manajemen Bisnis, 1(1), h: 92-110.

Wardani, Hesti Kusuma. 2011. Pengaruh Struktur Aktiva, Ukuran Perusahaan, Profitabilitas, dan Operating Leverage terhadap StrukturModal pada PerusahaanProperty dan Real Estate yangTerdaftar di BEI. Skripsi,. Universitas Gunadarma, Jakarta.

Weston, J.F., dan Thomas E. Copeland. 2008. Dasar-Dasar Manajemen Keuangan Jilid II. Jakarta : Erlangga.

Winahyuningsih, Panca, Kertati Sumekar, dan Hanar Prasetyo. 2010. Analisis Faktor-Faktor Yang Mempengaruhi Struktur Modal Pada Perusahaan Manufaktur Yang Go Public Di Bursa Efek Indonesia. Sosial dan Budaya, 4(1), h: 24-41.

Yusrianti, Hasni. (2013). Pengaruh Tingkat Profitabilitas, Struktur Asset, dan Growth Opportunity Terhadap Struktur Modal Pada Perusahaan Manufaktur yang Telah Go Public Di Bursa Efek Indonesia. Seminar Hasil Penelitian FE Unsri, 26 Oktober 2013, Palembang, Indonesia. 